Article Type: Research Paper

\title{
Dynamic Tourism in ASEAN Countries: Do Institutional Indicators Matter?
}

\author{
Vita Kartika Sari* and Malik Cahyadin
}

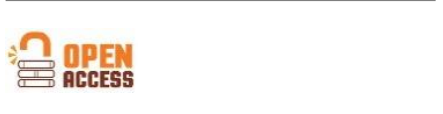

\section{AFFILIATION:}

Department of Development Economics, Faculty of Economics and Business, Universitas Sebelas Maret, Central Java, Indonesia

\section{*CORRESPONDENCE:}

vitahanifanaira@gmail.com

THIS ARTICLE IS AVALILABLE IN:

http://journal.umy.ac.id/index.php/esp

DOI: 10.18196/jesp.v22i2.11282

\section{CITATION:}

Sari, V.K., \& Cahyadin, M. (2021). Dynamic Tourism in ASEAN Countries: Do Institutional Indicators Matter? Jurnal Ekonomi \& Studi Pembangunan, 22(2), 201212.

\section{ARTICLE HISTORY}

Received:

07 Mar 2021

Revised:

03 Jun 2021

Accepted:

10 Sep 2021

\begin{abstract}
Tourism is one of the fastest-growing industries. Tourism is able to move the economy forward at the micro-level such as encouraging the informal sector and local potential while at the macro level it can increase currency transactions. In various countries, the tourism sector is able to increase domestic and foreign demands as well as to encourage transportation, hospitality, and manufacturing industries. This study examines the effect of institutional indicators on tourism in ASEAN countries during 2000-2018 under dynamic panel estimation. The number of observations was about 180, namely: time series from 2000-2018 and cross-section of 10 countries. ASEAN as one of the destinations in the world requires an increase in institutional quality to be able to compete and provide world-class tourism services. The six institutional indicators were employed such as voice and accountability, political stability and absence of violence, government effectiveness, regulatory quality, rule of law, and control of corruption. Moreover, the dynamic panel estimation was expressed by Pooled OLS and REM estimations. Interestingly, the findings show that political stability compromises the number of tourist arrivals while government effectiveness can stimulate tourist arrivals. Similarly, GDP per capita can hinder the number of tourist arrivals, while the exchange rate leads increasing of tourism arrivals. Thus, the governments in ASEAN countries can promote and cooperate together to develop tourism in the regional level. The GDP per capita of ASEAN countries should be increased, and the level of exchange rate can be maintained at a stable range. Besides, the governments should also improve the quality of institutions. Keywords: Tourism; Institutions; Dynamic Panel

JEL Classification: 017; 043; Z32
\end{abstract}

\section{Introduction}

Tourism is one of the fastest-growing industries in the world. Tourism activities become one of the economic drivers and sources of foreign exchange reserves for a country. The development of tourism leads to the accelerated growth of the tourism business in accordance with the needs and expenses of modern society for travel and entertainment. ASEAN member countries have a strategic plan for tourism development in the 2016-2025 period because of the contribution to ASEAN economic growth. Furthermore, a country will provide tourist facilities and promote tourist uniqueness to attract both domestic and foreign tourists in significant numbers. 
For example, the 2019 Travel \& Tourism Competitiveness Index (TTCI) showed that Singapore was ranked first in tourism competitiveness in Southeast Asia, followed by Malaysia, Thailand, Indonesia, Vietnam, Brunei Darussalam, and the Philippines. Meanwhile, the World Bank noted an increase in the number of tourists over the past 10 years in ASEAN, particularly Malaysia, Thailand, Singapore, and Indonesia. Mohamad and Ab Ghani (2014) argued that tourism is one of the largest industries in the world that stimulates economic growth, income distribution, employment opportunities, and foreign currency transactions. The tourism industry has significantly boosted economic growth in developing countries. Tourism encourages exports, reduces unemployment, encourages micro and small businesses, and stimulates the regional economy (Samimi et al., 2011). Haseeb et al. (2019) described that tourism growth in ASEAN is very fast and has longterm potentials for state revenue.

Demand or tourist arrivals in the tourism industry can be determined by the availability of facilities, uniqueness, and quality of services. Simply put the better the service, the demand will increase. Several works of literature mentioned the importance of service quality as stated by Albacete-Saez et al. (2007) that infrastructure and excellent service attract subsequent visits and increase income. Mola and Jusoh (2011) and Padlee et al. (2019) confirmed that service quality is a key element in the hospitality industry that supports the tourism industry. Moreover, Canny (2013) described service quality is a competitiveness key in the tourism industry as well as a characteristic compared to other tourist attractions.

Furthermore, the tourism industry is also linked with various business and environmental challenges such as fluctuating economic conditions, weather changes, service quality, and business competition. A sustainable tourism industry requires good institutional support, such as infrastructures, telecommunications, security and political stability, and regulation. The institutional issues of tourism literature are rarely studied so it opens up a deeper discussion. Good institutions can sustain economic activity (North, 1990), furthermore, Lee et al. (2020), as well as Khan et al. (2020), proved that institutions have the potential to encourage the tourism sector.

This study contributes to the existing literature in several ways. The first contribution is to examine the impact of institutional indicators on dynamic tourism in ASEAN countries. Some previous empirical studies argued that institutions can promote tourism development. (Chatzigeorgiou \& Simeli, 2017; Kastenholz et al., 2012; Khan et al., 2020; Lee et al., 2020; Rahajeng, 2017). However, the previous studies largely ignore to estimate the dynamic estimation of tourism under six institutional indicators published by the World Governance Indicators (WGI) of the World Bank. Lee et al. (2020) used World Bank institutional indicators namely control of corruption, regulatory quality, government effectiveness, rule of law, political stability and absence of violence, and voice and accountability. The control of corruption had a positive influence on Malaysian tourism but a negative influence on economic output. Government effectiveness showed a positive influence on tourism but indicated a negative sign on economic growth. This study also selects some macroeconomic data as explanatory variables such as GDP per capita and exchange rate. These indicators are mostly utilized by previous studies to 
determine tourist arrivals analysis both in a country level and across the country level. Changes in lifestyle lead to high demand for services, especially tourism services, causing its rapid growth. Lee et al. (2020) mentioned that the high demand for leisure can be in the form of adventure, cultural tourism, religious tourism, wildlife, and ecotourism. Tourism service providers strive to provide the best deals in the form of attractive experiences at the best prices. Therefore, this study attempts to estimate the impact of institutional indicators on the number of tourist arrivals in ASEAN during 2000-2018. Previous studies (Lee et al., 2020) only analyzed the relationship between tourism and economic performance, where the macroeconomic perspective ideally incorporates institutions as a key factor in economic growth. Khan et al. (2020) affirmed the important role of institutions in running a tourism business. Khan et al. (2020) also stated that improvements in institutional quality can attract tourists to visit. Therefore, this study aimed to analyze institutional factors in the economic literature on tourism performance contributing to economic output.

Khan et al. (2020) analyzed the institutional impact on tourism in Selected Asian Pacific Countries with variables such as judicial independence, impartial courts, military interference in rule of law and politics, protection of property rights, reliability of police, the integrity of the legal system, enforcement of contracts, regulatory restrictions on the sale of real property, and business costs of crime, also credit market regulations, business regulations, and labor market regulations. Lee et al. (2020) used institutional indicators such as control of corruption, government effectiveness, regulatory quality, rule of law, voice and accountability, political stability, and absence of violence on Malaysian tourism. Rahajeng (2017) analyzed the institutional influence of local government policies on tourism in Yogyakarta.

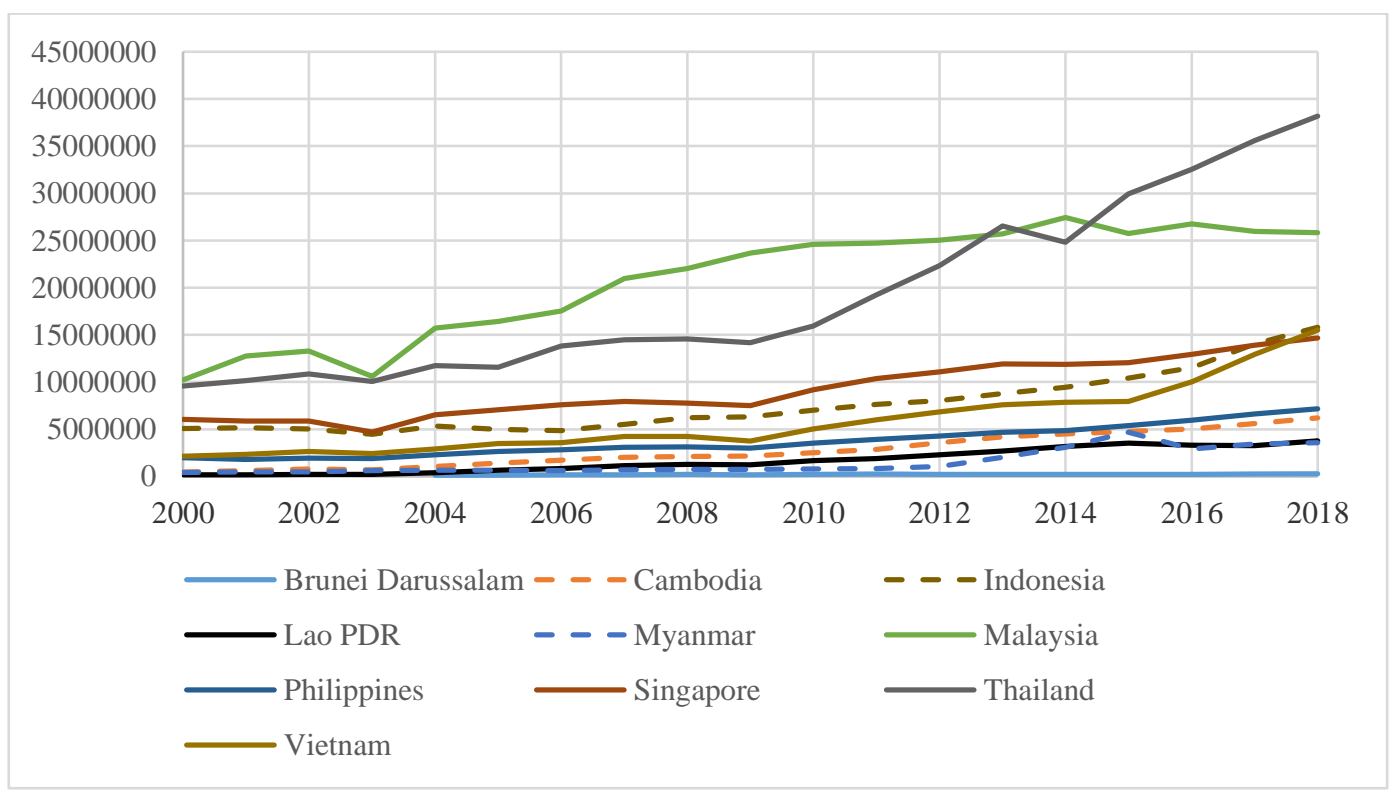

Figure 1 Number of Tourists in ASEAN Countries during 2000-2018 (person) Source: World Bank, 2020 


\author{
Sari \& Cahyadin \\ Dynamic Tourism in ASEAN Countries: Do Institutional Indicators Matter?
}

The World Bank publication showed that the number of tourists in ASEAN countries tended to increase during 2000-2018 (Figure 1). Malaysia and Thailand were able to attract tourists to visit over time. These countries provided various tourist attractions, facilities, and information that make it easy and interesting for tourists around the world. In contrast, countries such as Brunei Darussalam, Cambodia, Lao PDR, and Myanmar were not able to increase the number of tourists in significant numbers. This condition was likely related to the institutional quality of these countries. Indeed, institutional quality becomes a critical issue in some ASEAN countries to attract tourist arrivals.

In the literature, tourism is capable in driving the economic performance of developing countries by increasing foreign currency transactions to opening up new employment opportunities (Samimi et al., 2011). Moreover, tourism Led-Growth hypothesis explains that international tourism contributes as a source of national income, through exchange rate and export channels (Brida \& Risso, 2009; Ohlan, 2017; Ribeiro \& Wang, 2020; Samimi et al., 2011). Tourism encourages the emergence of creative industries which not only provide income for the community but also promote local creative products. In practice, the tourism industry has micro and macro impacts. At a micro level, it empowers informal sectors, raises the culture and potential of local tourism, promotes regional foods, and encourages hotel and transportation sectors. The industry will drive the national economy in the end. Therefore, the tourism sector is able to have a positive impact on the macroeconomy in a long term. It is reinforced by some evidence of the existence of several regions in Indonesia which are supported by the tourism industry such as Bali, the Special Region of Yogyakarta, and Lombok. Hence, Habibi et al. (2018) and Selimi et al. (2017) argued that the tourism sector is one of the largest service transactions in the world.

Moreover, this study bridges the empirical gap of institutions on tourism development. Indeed, institutional quality is a key factor in economic development (Khan et al., 2020). North (1990) argues that excellent institutional quality plays pivotal roles in economic, political, and social sectors. Meanwhile, poor institutional quality affects the performance of the tourism sector since the tourism industry is multi-sectoral and service-oriented. The findings discovered by Lee et al. (2020) show the importance of institutional issues such as government effectiveness and control of corruption which have a positive impact on tourist visits and generally increase the national income of Malaysia. Similarly, the institutional quality of institutions affects the number of tourist visits in Asia Pacific countries even though changes in institutional quality have not always been responded to by the increased number of tourist arrivals in Asia Pacific countries (Khan et al., 2020). The findings of previous empirical studies exhibit largely limited studies of the impact of institutions on dynamic tourism development. Thus, this study focuses on the dynamic analysis of tourism in ASEAN countries during 2000-2018.

\title{
Research Method
}

This study utilized secondary data published by the World Bank during 2000-2018. The dependent variable was the number of tourist arrivals (person). It was converted into a 
logarithm in the estimation model (LTA). Meanwhile, the independent variables covered GDP per capita (GDPC, current USD), exchange rates (er, LCU per USD), and institutional indicators (index between -2.5 to 2.5 ). The value of -2.5 equaled weak institutional quality while the value of 2.5 equaled strong institutional quality. Moreover, there were six institutional indicators i.e. voice and accountability (VA), political stability and absence of violence (PST), government effectiveness (GE), regulatory quality (RQ), rule of law (RL), and control of corruption (CC). Macroeconomic variables namely GDP/capita, real exchange rate, and inflation had a strong influence on tourism arrivals. Institutional variables namely political stability, voice and accountability, government effectiveness, regulatory quality, rule of law, and control of corruption had a positive influence on increasing tourism arrivals.

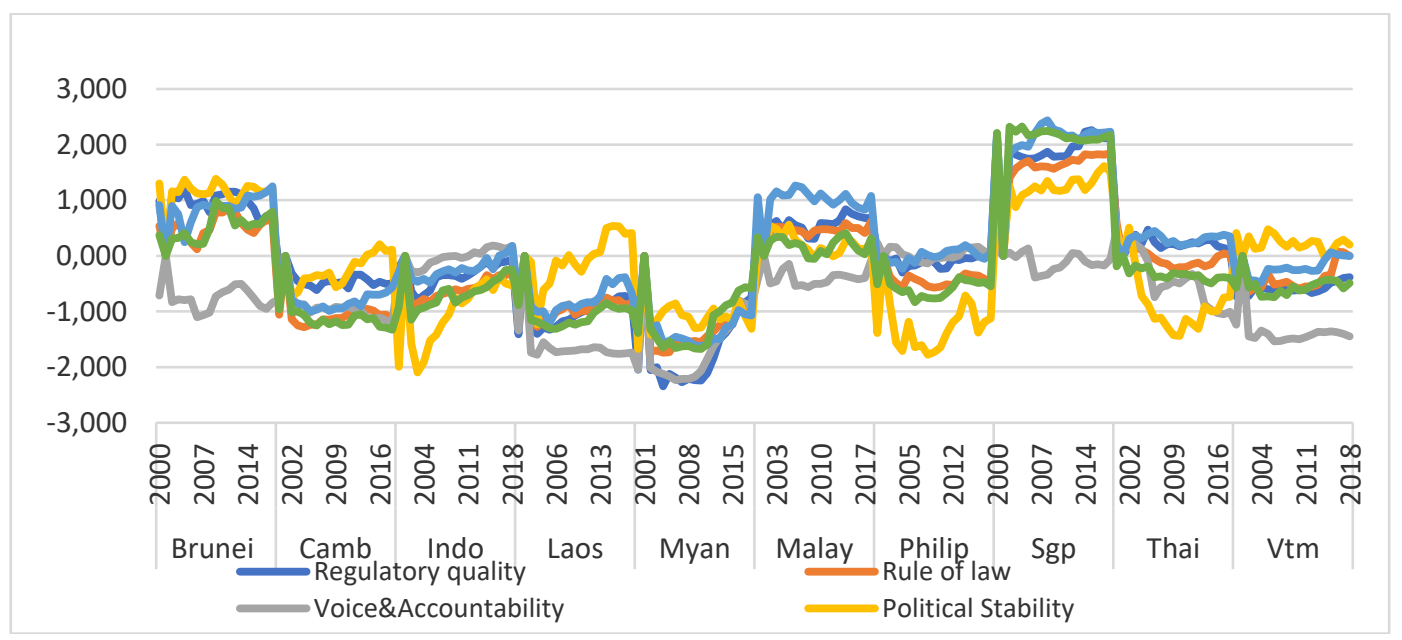

Figure 2 Institutions Quality in ASEAN Countries during 2000-2018 Source: World Bank, 2020

Table 1 Definition of Operational Variable

\begin{tabular}{|c|c|c|}
\hline Data/Variable & Definition of Variables & Data Source \\
\hline Number of tourism arrivals (TA) & Person. & World Bank \\
\hline GDP per capita (GDPC) & (Current US\$). & World Bank \\
\hline Inflation (INF) & Consumer prices (annual \%). & World Bank \\
\hline Official exchange rate (ER) & (LCU per US\$, period average). & World Bank \\
\hline Political stability (POL) & $\begin{array}{l}\text { Ranges from approximately - } 2.5 \text { (weak) to } \\
2.5 \text { (strong) governance performance. }\end{array}$ & World Bank \\
\hline Voice \& Accountability (VA) & $\begin{array}{l}\text { Ranges from approximately - } 2.5 \text { (weak) to } \\
2.5 \text { (strong) governance performance. }\end{array}$ & World Bank \\
\hline Government effectiveness (GE) & $\begin{array}{l}\text { Ranges from approximately - } 2.5 \text { (weak) to } \\
2.5 \text { (strong) governance performance. }\end{array}$ & World Bank \\
\hline Regulatory quality (RQ) & $\begin{array}{l}\text { Ranges from approximately - } 2.5 \text { (weak) to } \\
2.5 \text { (strong) governance performance. }\end{array}$ & World Bank \\
\hline Rule of law (RL) & $\begin{array}{l}\text { Ranges from approximately - } 2.5 \text { (weak) to } \\
2.5 \text { (strong) governance performance. }\end{array}$ & World Bank \\
\hline Control of Corruption (CC) & $\begin{array}{l}\text { Ranges from approximately - } 2.5 \text { (weak) to } \\
2.5 \text { (strong) governance performance. }\end{array}$ & World Bank \\
\hline
\end{tabular}


This study develops the empirical study conducted by Lee et al. (2020) in two forms, namely: the number of institutional indicators consisting of six indicators, and an empirical technique of dynamic panel data. The dynamic panel model developed by Pesaran (2015) explains that the lag of the dependent variable becomes one of the independent variables. Hence, this study formulates the dependent variable which can be expressed in the logarithm form of tourist arrivals (LTA) as determined by GDP per capita (GDPC), the exchange rate (ER), and six institutional indicators. The empirical model of dynamic panel data can be written as follows:

$\mathrm{LTA}_{\mathrm{it}}=\alpha_{0}+\beta_{1} \mathrm{LTA}_{\mathrm{it}-1}+\beta_{2} \mathrm{GDPC}_{\mathrm{it}}+\beta_{3} \mathrm{ER}_{\mathrm{it}}+\sum_{j=1}^{6} \beta_{j} X_{i t}+\varepsilon_{\mathrm{it}}$

Equation (1) denotes a Pooled OLS or Common Effects Model (CEM) that can be developed into a Fixed Effect Model (FEM) and Random Effects Model (REM) equations in Equation (2) and (3), respectively.

$$
\begin{aligned}
& \mathrm{LTA}_{\mathrm{it}}=\alpha_{0}+\alpha_{1} \mathrm{D}_{\mathrm{ni}}+\beta_{1} \mathrm{LTA}_{\mathrm{it}-1}+\beta_{2} \mathrm{GDPC}_{\mathrm{it}}+\beta_{3} \mathrm{ER}_{\mathrm{it}}+\sum_{j=1}^{6} \beta_{j} X_{i t}+\varepsilon_{\mathrm{it}} \\
& \mathrm{LTA}_{\mathrm{it}}=\alpha_{0}+\beta_{1} \mathrm{LTA}_{\mathrm{it}-1}+\beta_{2} \mathrm{GDPC}_{\mathrm{it}}+\beta_{3} \mathrm{ER}_{\mathrm{it}}+\sum_{j=1}^{6} \beta_{j} X_{i t}+\mathrm{w}_{\mathrm{it}}
\end{aligned}
$$

Equation 2 uses FEM which includes dummy variables to see the difference in parameters across time and across cross-section units. Equation 3 uses REM where different parameters between regions and between times are included in the error component. The $\alpha_{0}$ equals intercept while $\beta_{1}, \beta_{2}, \beta_{3}$, and $\beta_{4}$, are parameters/slope of the equation. Furthermore, the i denotes the cross-section of ASEAN 10 countries, $t$ is the time series of 2000-2018, $\mathrm{j}$ is the number of institutional indicators, and $\mathrm{X}$ is six institutional indicators. Gujarati (2003) affirmed that the panel model has many advantages, so a classical assumptions test is no longer needed.

\section{Result and Discussion}

Descriptive statistics inform the distribution of the data. In general, there are several descriptive statistics indicators as explained in Table 1 including the mean, standard deviation, minimum, and maximum values. For example, the mean of institutional indicators in ASEAN countries during 2000-2018 was below 1. It means that the level of institutional quality in these countries was relatively weak. Thus, governments in ASEAN need to be more concerned on the quality of institutions.

This study estimates the impact of institutional indicators on the number of tourist arrivals in ASEAN countries during 2000-2018. It also selects some macroeconomic data as explanatory variables such as GDP per capita and exchange rate. The dynamic panel data were employed under three methods, namely: Pooled OLS (POLS), Fixed Effects Model (FEM), and Random Effects Model (REM). The POLS and REM estimation shows that the dynamic panel model of tourist arrivals in ASEAN during the study period occurred. 
However, the lagged number of tourist arrivals has a negative impact on the current number of tourist arrivals.

Table 2 Descriptive Statistics

\begin{tabular}{lccccc}
\hline \multicolumn{1}{c}{ Variable } & Mean & Std. Dev. & Min & Max & Observations \\
\hline LTA & 14.77 & 2.31 & 2.00 & 17.00 & $\mathrm{~N}=190$ \\
GDPC & 9401.21 & 15152.92 & 137.00 & 64582 & $\mathrm{~N}=190$ \\
ER & 4209.876 & 6128.39 & 1.25 & 22602 & $\mathrm{~N}=190$ \\
VA & -0.71 & 0.69 & -2.2 & 0.46 & $\mathrm{~N}=190$ \\
PST & -0.17 & 0.91 & -2.09 & 1.61 & $\mathrm{~N}=190$ \\
GE & 0.09 & 0.98 & -1.61 & 2.43 & $\mathrm{~N}=190$ \\
RQ & -0.05 & 1.00 & -2.34 & 2.26 & $\mathrm{~N}=190$ \\
RL & -0.21 & 0.86 & -1.74 & 1.84 & $\mathrm{~N}=190$ \\
CC & -0.264 & 0.98 & -1.673 & 2.32 & $\mathrm{~N}=190$ \\
\hline
\end{tabular}

Table 3 Dynamic Panel Estimation Result

\begin{tabular}{|c|c|c|c|c|}
\hline \multicolumn{2}{|l|}{ Variable } & Pooled OLS & Fixed Effects & Random Effects \\
\hline \multicolumn{2}{|l|}{$\operatorname{LTA}(-1)$} & $-4.587[-2.01]^{* *}$ & $-0.150[-0.10]$ & $-4.5870[-2.01]^{* *}$ \\
\hline \multicolumn{2}{|l|}{ GDPC } & $-0.000[-2.55]^{* *}$ & $0.000[4.43]^{* * *}$ & $-0.000[-2.55]^{* *}$ \\
\hline \multicolumn{2}{|l|}{ ER } & $0.000[2.96]^{*}$ & $0.000[1.80]^{*}$ & $0.000[2.96]^{* * *}$ \\
\hline \multicolumn{2}{|l|}{ VA } & $-0.463[-1.13]$ & $-0.891[-2.11]^{* *}$ & $-0.463[-1.13]$ \\
\hline \multicolumn{2}{|l|}{ PST } & $-1.221[-3.79]^{* * *}$ & $0.621[2.07]^{* *}$ & $-1.221[-3.79]^{* * *}$ \\
\hline \multicolumn{2}{|l|}{ GE } & $1.642[2.07]^{* *}$ & $-0.124[-0.19]$ & $1.642[2.07]^{* *}$ \\
\hline \multicolumn{2}{|l|}{$R Q$} & $0.147[0.23]$ & $0.928[1.50]$ & $0.147[0.23]$ \\
\hline \multicolumn{2}{|l|}{ RL } & $0.028[0.03]$ & $-1.760[-2.03]^{* *}$ & $0.028[0.03]$ \\
\hline \multicolumn{2}{|l|}{ CC } & $0.289[0.46]$ & $1.052[1.57]$ & $0.289[0.46]$ \\
\hline \multicolumn{2}{|l|}{ Constant } & $14.484[31.84]^{* * *}$ & $12.876[28.32]^{* * *}$ & $14.484[31.84]^{* * *}$ \\
\hline \multicolumn{5}{|c|}{ R-square: } \\
\hline & Within & 0.0062 & 0.2507 & 0.0062 \\
\hline & Between & 0.6808 & 0.1143 & 0.6808 \\
\hline & Overall & 0.2912 & 0.0245 & 0.2912 \\
\hline \multicolumn{2}{|c|}{ Wald Chi-square } & $69.83 * * *$ & $5.99 * * *$ & $69.83 * * *$ \\
\hline \multicolumn{5}{|c|}{ (F-statistics) } \\
\hline \multicolumn{2}{|l|}{ LM Test } & \multicolumn{3}{|c|}{0.00} \\
\hline \multicolumn{3}{|c|}{ Hausman Test } & \multicolumn{2}{|c|}{$40.51^{* * *}$} \\
\hline Observat & & 180 & 180 & 180 \\
\hline
\end{tabular}

Note: [] denotes Z statistics; ***, ** and * denote significant levels at $1 \%, 5 \%$ and $10 \%$, respectively

FEM estimation describes that dynamic model of tourism in ASEAN countries did not occur. In the FEM method results, the lag of tourist arrival had no influence on the number of tourist visits. Surprisingly, some institutional indicators determined the number of tourist arrivals such as voice and accountability, political stability and absence of violence, and rule of law. Besides, the GDP per capita and the exchange rate had a positive impact and significant on the number of tourist arrivals. Furthermore, the Hausman test confirmed that FEM was an appropriate static panel model. 
Moreover, the REM estimation shows that a dynamic panel model of tourist arrivals in ASEAN countries occurred. It means that the number of tourist arrivals in the current period was determined by the number of tourist arrivals in the previous period. However, the finding expresses that the lag of tourist arrivals had a negative impact on the current tourist arrivals. Besides, GDP per capita and political stability had a significant and negative impact on the number of tourist arrivals while the exchange rate had a significant and positive impact. Political stability had a significant and negative effect. Foreign tourists are not willing to carry out tourism activities if there is no guarantee of political stability which involves security and safety.

The goodness of fit of the empirical model can be expressed by the within R-square of FEM which was estimated higher than POLS and REM (0.2507>0.0062). Meanwhile, the between R-square of FEM was estimated lower than POLS and REM $(0.1143<0.6808)$. It indicates that the within-group FEM estimation was more appropriate. Besides, the Fstatistics of all estimation models were significant. This indicates the independent variables had a significant influence on the dependent variable simultaneously.

The findings of this study bring to the scholarly discussion of a nowadays institutional framework called as the New Institutional Economy (NIE). NIE offers balanced ideas between the government, business people, and even ordinary people. NIE offers important variables in economic activities that play a role in efforts to economic growth, such as the patent, ease of establishing a business, transaction costs, to administrative complexity that has not yet been "considered". Furthermore, Santosa (2008) explained that NIE is present because of frequent market failures, such as asymmetric market information conditions, externalities, to the existence of public goods. NIE also focuses on studies of institutional failures that occur in many countries. According to NIE, there is a structured relationship between institutions and economics, that is, economic conditions will determine the shape of the institutional structure. Economic transactions can only occur because of the existence of an institution. Thus, this study can exhibit a significant contribution of institutions to tourism in ASEAN countries.

Some previous empirical studies found that tourism institutions such as social, emotional, and symbol were significant to realize tourist satisfaction (Kastenholz et al., 2012). It indicates that high levels of institutions will have an indirectly significant impact on the number of tourist arrivals. Chatzigeorgiou and Simeli (2017) also argued that dynamic service quality will drive visitor satisfaction. The empirical study on the role of government in tourism development has been carried out by Rahajeng (2017). The findings showed that the local government contributed to the development of tourism facilities, marketing, and improvement of the institutional framework. Meanwhile, the findings of this study are macro in nature, emphasizing a number of macroeconomic indicators and six institutional indicators. Specifically, Lee et al. (2020) shows the significant impact of institutional indicators such as government effectiveness and control of corruption on tourist visits and the national income of Malaysia. The results found a dynamic model of tourist visits in ASEAN in general. Based on FEM, voice and accountability were significant. Based on the pooled method, FEM, and REM, political stability and the absence of violence were significant, indicating that the tourism industry needs support for 
conducive governance with guaranteed security. Based on pooled model and REM, government effectiveness was significant showing that the efficiency of public services can support the tourism sector. Based on FEM, the rule of law had a significant influence on tourist arrival in ASEAN, where if the rule of law is not upheld based on justice, it can reduce the interest of tourists visiting ASEAN.

This study has employed some macroeconomic indicators to determine dynamic tourist arrivals in ASEAN countries. Some previous studies largely concerned on the linkage between economic growth and tourism. Leana et al. (2014) examined the correlation between economic growth and the tourism sector in Malaysia and Singapore. Similar findings were reported by Atan and Arslanturk (2012) and Zortuk (2009) that there is a one-way correlation between tourism sector performance and economic growth in Turkey, a long-run relationship between economic growth and the number of tourist arrivals, and significant contribution of restaurants and hotels in the tourism business. In addition, Kumar et al. (2014) found that tourism has a negative impact on the economy of Malaysia in the short-run. While a positive impact in the long-run. Specifically, the tourism industry of Malaysia also drives productivity by increasing labor and stimulating investment. Lee et al. (2020) found an important role in the control of corruption and government effectiveness to encourage tourism in Malaysia. The effectiveness of government administration has a significant influence on tourist visits in Malaysia.

Table 4 Two-Step Dynamic Panel of System GMM Estimation

\begin{tabular}{|c|c|}
\hline Variable & LTA \\
\hline c & $52.37(2.81)^{* * *}$ \\
\hline $\operatorname{LTA}(-1)$ & $-1.87(-2.34)^{* *}$ \\
\hline LGDPC & $1.24(2.19)^{* *}$ \\
\hline LER & $1.05(3.75)^{* * *}$ \\
\hline VA & $33.79(2.72)^{* * *}$ \\
\hline PST & $16.61(2.56)^{* *}$ \\
\hline GE & $2.34(1.24)$ \\
\hline RQ & $-29.89(-2.73) * * *$ \\
\hline $\mathrm{RL}$ & $25.34(2.65)^{* * *}$ \\
\hline $\mathrm{CC}$ & $-25.25(-2.70)^{* * *}$ \\
\hline Sargan test & 0.00 \\
\hline (p-value) & $(1.00)$ \\
\hline Autocorrelation of Order 1 & -0.53 \\
\hline (p-value) & (0.59) \\
\hline $\mathrm{N} \times \mathrm{T}$ & $10 \times 3$ \\
\hline
\end{tabular}

Note: All models are estimated using the Blundell and Bond (1998) estimations. The result is no autocorrelation. Figures in the parentheses are t-statistics. $* * *, * *$ and ${ }^{*}$ indicate significance at the $1 \%, 5 \%$, and $10 \%$ levels, respectively.

This study estimated Equation (1)-(3) by using a two-step system generalized method of moment (GMM) estimator developed by Blundell and Bond (1998). The GMM system estimated the equations in the combination of level and difference and lagged level of the regressor. Furthermore, the two-step GMM system can produce efficient estimates. The data period was made an average of 5 years resulting in 4 categories of data series namely 
2000-2004, 2005-2009, 2010-2014, and 2015-2018. Based on the robustness test by using the GMM Arellano-Bond two-step estimator, all institutional variables were significant, except the government effectiveness. The dynamic panel method using the ArellanoBond GMM approach can be said to be good if it meets the criteria for consistency and instrument validity. Based on Table 3, the dynamic panel method using the Arellano-Bond GMM approach has met the criteria for the best model, both statistically consistent and valid. The Sargan test results showed no correlation between residuals and overidentifying restrictions or the instrument variable used more than the number of suspected parameters. Accordingly, there is no problem with validity. When compared to Table 3, GMM is more efficient and has more significant independent variables.

\section{Conclusion}

This study examines dynamic panel models of tourist arrivals in ASEAN countries during 2000-2018. Institutional indicators are endogenous factors in economic activity, so this study contributes to the institutional analysis literature on the formation of economic output through the tourism sector. The number of tourist arrivals was determined by some institutional indicators. Empirically, there are six institutional indicators published by World Governance Indicators (WGI) under the World Bank. Moreover, there were two macroeconomic data selected as explanatory variables such as GDP per capita and exchange rates. Besides, the Pooled OLS and Random Effects Model (REM) have exhibited the dynamic panel model of tourist arrivals in ASEAN countries. However, FEM indicates the dynamic panel model of tourist arrivals did not occur. Interestingly, the Hausman test indicates that FEM was an appropriate model of static panel data.

The findings exhibit that under Pooled OLS and REM there are two institutional indicators i.e. political stability and government effectiveness that can determine the number of tourist arrivals in ASEAN countries during the study period. In addition, the macroeconomic data comprising GDP per capita and exchange rate also significantly contribute to the number of tourist arrivals. This study summarizes that government effectiveness and exchange rate can underpin the number of tourist arrivals in ASEAN while the political stability and GDP per capita undermine the number of tourist arrivals. Institutional significance such as voice and accountability, political stability and absence of violence, government effectiveness, and the rule of law underlies the results. The governments of ASEAN countries must maintain government effectiveness, improve public services, and reduce corruption in order to create a stable and conducive life. In the long run, it will boost the tourism sector's performance. Good institutional quality standards encourage the tourist's arrival.

Some policy implications can be formulated such that the governments of ASEAN countries should improve the quality of institutions through better the provision of public goods, procedural simplifications, and conducive political stability. Moreover, they can collaborate intensively to formulate macroeconomic policies such as promoting a high level of GDP per capita and maintaining the level of the exchange rate at a stable range. 


\section{Sari \& Cahyadin \\ Dynamic Tourism in ASEAN Countries: Do Institutional Indicators Matter?}

\section{References}

Albacete-Sáez, C. A., Mar Fuentes-Fuentes, M., \& Javier Lloréns-Montes, F. (2007). Service quality measurement in rural accommodation. Annals of Tourism Research, 34(1), 45-65. https://doi.org/10.1016/i.annals.2006.06.010

Atan, S., \& Arslanturk, Y. (2012). Tourism and economic growth nexus: an input output analysis in Turkey. Procedia - Social and Behavioral Sciences, 62, 952-956. https://doi.org/10.1016/i.sbspro.2012.09.162

Blundell, R., \& Bond, S. (1998). Initial conditions and moment restrictions in dynamic panel data models. Journal of Econometrics, 87, 115-143. https://doi.org/10.1016/s03044076(98)00009-8

Brida, J. G., \& Risso, W. A. (2009). Tourism as a factor of long-run economic growth: An empirical analysis for Chile. European Journal of Tourism Research, 2(2), 178-185. Retrieved from https://www.proquest.com/scholarly-journals/tourism-as-factorlong-run-economic-growth/docview/89159825/se-2? accountid=187856

Canny, I. U. (2013). An empirical investigation of service quality, tourist satisfaction and future behavioral intentions among domestic local tourist at Borobudur temple. International Journal of Trade, Economics and Finance, 86-91. https://doi.org/10.7763/ijtef.2013.v4.265

Chatzigeorgiou, C., \& Simeli, I. (2017). Perception of service quality in agrotourism accommodations: impact on guest loyalty and revisit intentions. Journal of Tourism, Heritage \& Services Marketing, 3(1), 33-41. Retrieved from https://www.jthsm.gr/vol3iss1/3-1-5.pdf

Gujarati, D.N. (2003). Basic econometrics. McGraw Hill.

Habibi, F., Rahmati, M., \& Karimi, A. (2018). Contribution of tourism to economic growth in Iran's provinces: gdm approach. Future Business Journal, 4, 261-271. https://doi.org/10.1016/j.fbj.2018.09.001

Haseeb, M., Zandi, G., Andrianto, N. M., \& Chankoson, T. (2019). Impact of macroeconomic indicators on development patterns: case of tourism industry in Asean region. Journal of Security and Sustainability Issues, 9(1), 257-268. https://doi.org/10.9770/jssi.2019.9.1(19)

Kastenholz, E., Carneiro, M. J., Peixeira Marques, C., \& Lima, J. (2012). Understanding and managing the rural tourism experience - The case of a historical village in Portugal. Tourism Management Perspectives, 4, 207-214. https://doi.org/10.1016/j.tmp.2012.08.009

Khan, M. A., Popp, J., Talib, M. N. A., Lakner, Z., Khan, M. A., \& Oláh, J. (2020). Asymmetric impact of institutional quality on tourism inflows among selected Asian Pacific countries. Sustainability, 12(3), 1223. https://doi.org/10.3390/su12031223

Kumar, R. R., Loganathan, N., Patel, A., \& Kumar, R. D. (2014). Nexus between tourism earnings and economic growth: a study of Malaysia. Quality \& Quantity, 49(3), 11011120. https://doi.org/10.1007/s11135-014-0037-4

Leana, H. H., Chong, S. H., \& Hooy, C. W. (2014). Tourism and economic growth: comparing Malaysia and Singapore. International Journal of Economics and Management, 8(1), 139-157. Retrieved from http://scholar.google.com/scholar lookup?hl=en\&volume=8\&publication year $=201$ 4\&issue $=1$ \&author $=$ H. + Lean\&author $=$ S. + H. + Chong\&author $=$ C. + W. + Hooy\&title $\equiv$ Tourism + and + Economic + Growth $\% 3 \mathrm{~A}+$ Comparing + Malaysia + and + Singapore

Lee, H. S., Lee, S. Y., \& Har, W. M. (2020). Roles of institutional quality on the relationship between tourism and economic development in Malaysia. Joumal of Environmental Treatment Techniques, 8(1), 119-124. Retrieved from http://www.jett.dormaj.com/docs/Volume8/Issue $\% 201 /$ Roles $\% 20$ of $\% 20$ Institution 
al $\% 20$ Quality $\% 20$ on $\% 20$ the $\% 20$ Relationship $\% 20$ between $\% 20$ Tourism $\% 20$ and $\% 20 \mathrm{E}$ conomic $\% 20$ Development $\% 20$ in $\% 20$ Malaysia.pdf

Mohamad, M., \& Ab Ghani, N. I. (2014). Comparing destination image and loyalty between first-time and repeat-visit tourists. SHS Web of Conferences, $4^{\text {th }}$ International Conference on Tourism Research (4ICTR). https://doi.org/10.1051/shsconf/20141201047

Mola, F., \& Jusoh, J. (2011). Service quality in Penang hotels: a gap score analysis. World Applied Sciences Journal, 12, 19-24.

North, D. (1990). Institutions, institutional change and economic performance. Cambridge: Cambridge University Press.

Ohlan, R. (2017). The relationship between tourism, financial development and economic growth in India. Future Business Journal, 3(1), 9-22. https://doi.org/10.1016/j.fbj.2017.01.003

Padlee, S. F., Thaw, C. Y., \& Zulkiffli, S. N. 'A. (2019). The relationship between service quality, customer satisfaction and behavioural intentions in the hospitality industry. Tourism and Hospitality Management, 25(1), 121-139. https://doi.org/10.20867/thm.25.1.9

Pesaran, M. H. (2015). Time series and panel data econometrics. UK: Oxford University Press.

Rahajeng, A. (2017). The roles of Kulonprogo regional government in developing tourism economy: nature-based tourism. JKAP (Jurnal Kebijakan dan Administrasi Publik), 20(2), 50-63. https://doi.org/10.22146/jkap.16592

Ribeiro, E. da C., \& Wang, B. (2020). Tourism led growth hypothesis: has the tourism industry an impact on the economic growth of Sao tome and principe? International Journal of Economics and Financial Issues, 10(1), 180-185. https://doi.org/10.32479/ijefi.9105

Samimi, A. J., Sadeghi, S., \& Sadeghi, S. (2011). Tourism and economic growth in developing countries: P-VAR approach. Middle-East Journal of Scientific Research, 10(1), 28-32.

Santosa, P. B. (2008). Relevansi dan aplikasi aliran ekonomi kelembagaan. Jurnal Ekonomi Pembangunan: Kajian Masalab Ekonomi dan Pembangunan, 9(1), 46-60. https://doi.org/10.23917/jep.v9i1.1030

Selimi, N., Sadiku, S. L., \& Sadiku, M. (2017). The impact of tourism on economic growth in the Western Balkan countries: an empirical analysis. International Journal of Business and Economic Sciences Applied Research, 10(2), 19-25. https://doi.org/10.25103/ijbesar.102.02

World Bank. (2020). World Bank Open Data. Retrieved from https://data.worldbank.org/

Zortuk, M. (2009). Economic impact of tourism on Turkey's economy: evidence from cointegration tests. International Research Journal of Finance and Economics, 1(25), 231-239. 